\title{
Diurnal regulation of hypothalamic kisspeptin is disrupted during mouse pregnancy
}

\author{
Cassandra C Yap, Michaela D Wharfe, Peter J Mark, Brendan J Waddell and \\ Jeremy T Smith
}

School of Anatomy, Physiology and Human Biology, The University of Western Australia, Perth, Western Australia, Australia
Correspondence should be addressed to J T Smith

Email

jeremy.smith@uwa.edu.au

\begin{abstract}
Kisspeptin, the neuropeptide product of the Kiss 1 gene, is critical in driving the hypothalamic-pituitary-gonadal (HPG) axis. Kisspeptin neurons in the anteroventral periventricular nucleus (AVPV) and arcuate nucleus (Arc) of the hypothalamus mediate differential effects, with the Arc regulating negative feedback of sex steroids and the AVPV regulating positive feedback, vital for the preovulatory surge and gated under circadian control. We aimed to characterize hypothalamic Kiss 1 and Kiss $1 \mathrm{r}$ mRNA expression in nonpregnant and pregnant mice, and investigate potential circadian regulation. Anterior and posterior hypothalami were collected from C57BL/6J mice at diestrus, proestrus, and days $6,10,14$, and 18 of pregnancy, at six time points across $24 \mathrm{~h}$, for real-time PCR analysis of gene expression. Analysis confirmed that Kiss 1 mRNA expression in the AVPV increased at ZT13 during proestrus, with a luteinizing hormone surge observed thereafter. No diurnal regulation was seen at diestrus or at any stage of pregnancy. Anterior hypothalamic Avp mRNA expression exhibited no diurnal variation, but Avpr1a peaked at 12:00 $\mathrm{h}$ during proestrus, possibly reflecting the circadian input from the suprachiasmatic nucleus to AVPV Kiss1 neurons. Rfrp (Npvf) expression in the posterior hypothalamus did not demonstrate diurnal variation at any stage. Clock genes Bmal1 and Rev-erbo were strongly diurnal, but there was little change between diestrus/ proestrus and pregnancy. Our data indicate the absence of the circadian input to Kiss 1 in pregnancy, despite high gestational estradiol levels and normal clock gene expression, and may suggest a disruption of a kisspeptin-specific diurnal rhythm that operates in the nonpregnant state.
\end{abstract}

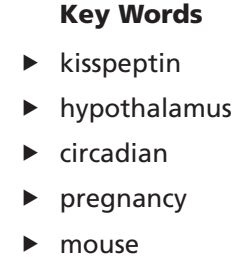

Journal of Endocrinology (2016) 229, 307-318

\section{Introduction}

Kisspeptin neurons are the afferent population that is critical for stimulation of gonadotropin-releasing hormone (GnRH) neurons, to drive the hypothalamic-pituitarygonadal (HPG) axis. Gonadal sex steroids exert feedback actions onto GnRH neurons via kisspeptin regulation, with kisspeptin populations in the anteroventral periventricular (AVPV) nucleus and arcuate (Arc) nucleus being involved in positive and negative feedback control of estradiol, respectively (Gottsch et al. 2004, Smith et al. $2005 a, b)$. Neurons expressing RFamide-related peptides

Published by Bioscientifica Ltd 
(RFRPs (NPVF)) such as RFRP-3, produced from a precursor peptide encoded by the neuropeptide VF precursor ( $N p v f)$ gene and the actions of which are conducted through the neuropeptide FF receptor (NPFFR) (Clarke et al. 2009), are found in the dorsomedial nucleus (DMN). RFRP-3 neurons are proposed inhibitors of GnRH secretion, which are thought to modulate the negative feedback effects of estrogen across most of the ovulatory cycle (Kriegsfeld et al. 2006, Ducret et al. 2009, Williams \& Kriegsfeld 2012). For a short period just before ovulation, estrogen feedback to the reproductive axis switches from negative to positive, and this causes a surge of GnRH and thus LH secretion from the pituitary (Karsch et al. 1997, Levine 1997). This switch is thought to be governed, in part, by the interplay between kisspeptin and RFRP3.

The pre-ovulatory LH surge that occurs in female rodents is a product of interactions between circadian inputs and estrogenic signals. Specifically, high concentrations of estradiol and a circadian signal predicting the onset of darkness are both essential for triggering the increase in kisspeptin levels and the subsequent LH surge (Levine 1997, Christian \& Moenter 2010, Williams et al. 2011). In female rodents, the LH surge is precisely timed to occur in the late afternoon of proestrus, being tightly controlled by the master circadian oscillator located in the suprachiasmatic nucleus (SCN) of the hypothalamus. Kisspeptin also appears to be under the circadian control, as evidenced by studies showing that increases in kisspeptin expression in the AVPV of the hypothalamus are synchronous with the LH surge during proestrus in female rats (Smith et al. 2006), mice (Robertson et al. 2009), and hamsters (Williams et al. 2011). Furthermore, studies in hamsters have shown that RFRP-3 cells are indirectly modulated via SCN vasoactive intestinal peptide (VIP)-ergic neurons (Russo et al. 2015) and act directly on GnRH neurons to inhibit their activity (Gibson et al. 2008). Data also suggest that RFRP-3 exhibits reduced expression during proestrus, and thus lowers GnRH inhibition and positively drives the GnRH/LH surge and ovulation (Gibson et al. 2008). Other studies showing that estrogen lowers RFRP3 mRNA levels also suggest that RFRP-3 may also play a role in estrogen positive feedback (Molnár et al. 2011, Poling et al. 2012).

Arginine vasopressin (AVP) neurons are responsible for the circadian input to the AVPV and originate from the dorsomedial SCN to contact kisspeptin neurons expressing the AVP receptor subtype V1a (Leak \& Moore 2001, Williams et al. 2011). As the master pacemaker, the SCN exerts tight circadian control over many biological processes through endogenous rhythms generated by positive and negative feedback gene transcription and translation loops of clock genes, including Clock, Bmal1, Per1-3, Cry 1-2, and Rev-erbo (Reppert \& Weaver 2001). These clock genes are also expressed in numerous peripheral tissues (Boden et al. 2010). We have recently shown that the expression of core clock genes in the SCN changes significantly across gestation in the mouse (Wharfe et al. 2016), and Wharfe and coworkers have also previously demonstrated that clock gene rhythms in the rat liver are altered by pregnancy (Wharfe et al. 2011). Additionally, despite the high estradiol levels during pregnancy, the HPG axis is dormant and ovulation does not occur, suggesting the shutdown of kisspeptin signaling, reduced GnRH neuron or gonadotrope sensitivity, or a combination of each. We therefore speculate that disruption of normal hypothalamic circadian rhythms, including those of kisspeptin in the AVPV, occurs in the pregnant state and suppresses brain mechanisms controlling ovulation. In this study, we sought to characterize the hypothalamic expression of the kisspeptin signaling system in the mouse during pregnancy, and to investigate whether this expression exhibits a circadian pattern, as is observed in proestrus females.

\section{Materials and methods}

\section{Animals}

Nulliparous C57Bl/6J mice (6 weeks old) were supplied by the Animal Resources Centre (Murdoch, Australia). Mice were maintained in an environmentally controlled room under a $12 \mathrm{~h}$ light: $12 \mathrm{~h}$ darkness cycle (lights on from 07:00 to 19:00 h) with access to food and water ad libitum. By convention in chronobiology, lights off at 19:00 h was defined as Zeitgeber time (ZT) 12, with sampling times described as relative to ZT12. Female mice were subjected to a daily vaginal smear to determine the estrous cycle stage and monitored for three full cycles. A subgroup of female mice was mated overnight, and pregnancy confirmed by observation of a vaginal plug the following morning, which was designated day 1 of pregnancy. Whole-brain and blood sample collections were made at $4 \mathrm{~h}$ intervals commencing at $08: 00 \mathrm{~h}$ on diestrus $\mathrm{II} /$ proestrus of the cycle or day $6,10,14$, or 18 of pregnancy (term $=19$ days). Diestrus and proestrus were chosen as days of the cycle as hormone levels and gene expression typically show the most variation between those two days. The days of pregnancy chosen represent developmental milestones: day 6 is postimplantation, day 10 is the embryonic http://joe.endocrinology-journals.org DOI: 10.1530/JOE-16-0086
C 2016 Society for Endocrinology Printed in Great Britain
Published by Bioscientifica Ltd. 
period, day 14 represents early fetal life, and day 18 late fetal life. We have previously shown that six time points (4h: intervals) are adequate for the determination of circadian regulation of genes (Wharfe et al. 2016). All procedures involving animals were conducted with the approval of the Animal Ethics Committee of the University of Western Australia, Perth, WA, Australia.

\section{Tissue collection}

Whole brains were collected from mice under isoflurane anaesthesia at 08:00h (ZT1), 12:00h (ZT5), 16:00h (ZT9), 20:00h (ZT13), 24:00h (ZT17), or 04:00h (ZT21) in order to obtain a reasonable circadian profile of gene expression and plasma hormone levels. A red light (>600 nm wavelength) was used to facilitate collection of tissues in the dark phase. Whole brains were frozen by being placed on dry ice immediately following removal. A blood sample was obtained from each mouse under anesthesia through a cardiac puncture and collected in a tube containing EDTA $(100 \mu \mathrm{L} / \mathrm{mL}$ of blood). Plasma was obtained following centrifugation of the blood sample and stored at $-20^{\circ} \mathrm{C}$ until required.

\section{Hypothalamic gene expression}

RNA extraction Hypothalami were dissected from whole-brain samples and bisected into anterior (containing the AVPV and SCN) and posterior (containing the ARC) portions as described by Quennell and coworkers (Quennell et al. 2011). Total RNA was extracted from anterior and posterior hypothalami using Qiazol (Qiagen) according to the manufacturer's instructions.
The RNA pellet was dissolved in $50 \mu \mathrm{L}$ of RNase-free water, placed on ice for $5 \mathrm{~min}$ and thoroughly vortexed. RNA was quantitated using the Nanodrop ND-1000 spectrophotometer (Thermo Scientific) at $260 \mathrm{~nm}$ and stored at $-80^{\circ} \mathrm{C}$ until required.

Reverse transcription RNA samples were treated with RQ1 RNase-free DNase (Promega, cat\# M6101) to remove any genomic DNA present in the sample. Reactions were made up to a total volume of $10 \mu \mathrm{L}$ with $1 \mu \mathrm{g}$ of RNA, $1 \mu \mathrm{L}$ of RQ1 RNase-Free DNase $10 \times$ Buffer, $2 \mu \mathrm{L}$ of RQ1 RNaseFree DNase and nuclease-free water, and incubated at $37^{\circ} \mathrm{C}$ for $30 \mathrm{~min}$. About $1 \mu \mathrm{L}$ of RQ1 DNase Stop Solution was added to each sample to terminate the reaction, and samples were incubated at $65^{\circ} \mathrm{C}$ for $10 \mathrm{~min}$ to deactivate the DNase.

Total RNA $(1 \mu \mathrm{g})$ was reverse transcribed to cDNA with random primers (Promega, cat\# C1181) using Moloney Murine Leukemia Virus Reverse Transcriptase, RNase $\mathrm{H}$ Minus, Point Mutant (M-MLV RT (H-)) (Promega, cat\# M3683). The resultant cDNAs were purified using the UltraClean PCR Clean-Up Kit (MoBio Laboratories, Carlsbad, CA, USA; cat\# 12500-250), according to the manufacturer's instructions.

Real-time PCR Analyses of mRNA levels for total Kiss1, Kiss1 receptor (Kiss1r), AVP (Avp), AVP receptor 1a (Avpr1a), neuropeptide VF precursor (Npvf), and NPFFR (Npffr) transcripts were carried out by quantitative RT-PCR on the Rotorgene 6000 (Corbett Life Science, Concorde, New South Wales, Australia) using iQ SYBR Green Supermix (Bio-Rad, cat\# 170-8880). Primers (Table 1) for total Kiss1,

Table 1 Primer sequences and conditions for quantitative PCR.

\begin{tabular}{|c|c|c|c|}
\hline Gene & Sequence & $\begin{array}{l}\text { Size } \\
(\mathrm{bp})\end{array}$ & $\begin{array}{l}\text { Annealing temp } \\
\left({ }^{\circ} \mathrm{C}\right)\end{array}$ \\
\hline Kiss1 & $\begin{array}{l}\text { F: 5'-CTCTGTGTCGCCACCTATGG-3' } \\
\text { R: 5'-AGGCTTGCTCTCTGCATACC-3' }\end{array}$ & 126 & 60 \\
\hline Kiss1r & $\begin{array}{l}\text { F: 5'-TGCTGGGAGACTTCATGTGC-3' } \\
\text { R: 5'-CATACCAGCGGTCCACACTC-3' }\end{array}$ & 102 & 60 \\
\hline Bmal1 & $\begin{array}{l}\text { F: 5'-CGTGCTAAGGATGGCTGTTC-3' } \\
\text { R: 5'-CTTCCCTCGGTCACATCCTA-3' }\end{array}$ & 166 & 60 \\
\hline Rev-erb $\alpha$ & $\begin{array}{l}\text { F: 5'-ATTGCCCAGGGGGCGAGAGA-3' } \\
\text { R: 5'-GCCAAAAGAGCGGGCAGGGT-3' }\end{array}$ & 292 & 60 \\
\hline Hprt & $\begin{array}{l}\text { F: 5'-GCAGTACAGCCCCAAAATGG-3' } \\
\text { R: 5'-AGTCTGGCCTGTATCCAACAC-3' }\end{array}$ & 80 & 60 \\
\hline Sdha & $\begin{array}{l}\text { F: 5'-ATGGAAAATGGGGAGTGCCG-3' } \\
\text { R: 5'-ACAGCTGAAGTAGGTTCGGC-3' }\end{array}$ & 123 & 60 \\
\hline$A c t b$ & $\begin{array}{l}\text { F: 5'-TCCACACCCGCCACCAG-3' } \\
\text { R: 5'-GGCCTCGTCACCCACATAG-3' }\end{array}$ & 197 & 62 \\
\hline
\end{tabular}


Kiss1r, Bmal1, and Rev-erb $\alpha$, and the reference genes hypoxanthine-guanine phosphoribosyltransferase (Hprt), succinate dehydrogenase subunit A (Sdha), and beta actin $(A c t b)$ were designed using Primer-BLAST (http://www. ncbi.nlm.nih.gov). Each of the selected primer pairs was positioned to span an intron to ensure that no product was amplified from genomic DNA. The resulting amplicons were sequenced to confirm specificity. Standard curves for each product were generated from gel-extracted PCR products (QIAquick Gel Extraction Kit, Qiagen) using tenfold serial dilutions and Rotorgene 6000 software. The PCR cycling conditions were as follows: initial denaturation at $95^{\circ} \mathrm{C}$ for $10 \mathrm{~min}$, followed by 40 cycles of denaturation at $95^{\circ} \mathrm{C}$ for $1 \mathrm{~s}$, annealing at $60^{\circ} \mathrm{C}$ for $15 \mathrm{~s}$, and extension at $72^{\circ} \mathrm{C}$ for $5 \mathrm{~s}$. Melt-curve analysis was carried out to confirm amplification specificity for each gene.

Primers for Avp, Avpr1a, Npvf, and Npffr were purchased as QuantiTect Primer Assays (Qiagen, cat\# QT00249389, QT00113169, QT00278551, QT001169196). The PCR conditions were as follows: initial activation $95^{\circ} \mathrm{C}$ for $5 \mathrm{~min}$, followed by 40 cycles of denaturation at $95^{\circ} \mathrm{C}$ for $5 \mathrm{~s}$, and combined annealing/extension at $60^{\circ} \mathrm{C}$ for $10 \mathrm{~s}$. Melt-curve analysis was carried out to confirm amplification specificity.

All target genes were standardized against housekeeping genes Hprt, Sdhat and Actb using the GeNorm algorithm (Vandesompele et al. 2002). No differences were seen in these genes across days or time points (data not shown).

\section{Plasma hormone analyses}

Pituitary hormones Plasma levels of folliclestimulating hormone (FSH), luteinizing hormone (LH), prolactin, and adrenocorticotropic hormone (ACTH) were measured in a $10 \mu \mathrm{L}$ sample using the Milliplex Map Mouse Pituitary Magnetic Bead kit (Merck Millipore; cat\# MPTMAG-49K) according to the manufacturer's instructions. The plate was run on a MAGPIX system (Luminex Corporation, Austin, TX, USA) with XPONENT software (Luminex) to analyze the median fluorescent intensity data and obtain analyte concentrations. The lower limits of detection for this assay are as follows: FSH, $9.5 \mathrm{pg} / \mathrm{mL}$; LH, $1.9 \mathrm{pg} / \mathrm{mL}$; and prolactin, $46.2 \mathrm{pg} / \mathrm{mL}$.

Steroid hormones Before assay, plasma samples $(50 \mu \mathrm{L})$ were extracted in $75 \mu \mathrm{L}$ of acetonitrile, vortexed for $5 \mathrm{~s}$, and incubated for $10 \mathrm{~min}$ at room temperature. Samples were centrifuged at $17,000 \boldsymbol{g}$ for $5 \mathrm{~min}$, and the supernatant was transferred into separate tubes. The samples were dried by using SpeedVac (Thermo Scientific) at the highest setting and reconstituted with $40 \mu \mathrm{L}$ of assay buffer for subsequent assay.

Plasma levels of estradiol and progesterone were measured in $25 \mu \mathrm{L}$ of extracted sample using the Milliplex Map multi species Steroid/Thyroid Hormone panel kit (Merck Millipore; cat \# STTHMAG-21K) according to the manufacturer's instructions. The plate was run on a MAGPIX system (Luminex Corporation) with XPONENT software to analyse the median fluorescent intensity data and obtain analyte concentrations. The lower limits of detection for this assay are as follows: estradiol, $16 \mathrm{pg} / \mathrm{mL}$; and progesterone, $90 \mathrm{pg} / \mathrm{mL}$.

\section{Statistical analysis}

Statistical analyses were conducted using GraphPad Prism 6 (GraphPad Software). Data are expressed as the mean \pm s.E.M., with an $n$ of 5-7 per ZT on each day measured. Differences were considered to be significant when $P<0.05$. One-way ANOVAs were used to analyze plasma estradiol, progesterone, prolactin, ACTH, and FSH levels. Two-way ANOVAs were used to analyze gene expression data and plasma LH levels, with day and time as factors, followed by Tukey's post hoc tests where appropriate. One-way ANOVAs with time as a factor were conducted within each day, where significant interaction effects were observed in two-way ANOVA analyses.

\section{Results}

\section{Hormone levels}

There was a significant effect of day on plasma LH concentrations $(P<0.001)$, which was highest at proestrus. Within proestrus, LH increased around two-fold between ZT5 and ZT17 $(P<0.05)$, and no diurnal variation was observed at diestrus or day 18 of pregnancy (Fig. 1A). Plasma FSH levels showed no difference between any of the days measured (Fig. 1B).

Plasma estradiol levels increased significantly during pregnancy, almost doubling from diestrus to day 18 of pregnancy $(P<0.05)$ (Fig. $1 C)$. Similarly, plasma progesterone levels rose dramatically during pregnancy, increasing 45 -fold by day $6(P<0.01)$ and 170 -fold by day $18(P<0.0001$; Fig. 1D). Plasma prolactin concentrations peaked at day 6 of pregnancy, increasing nearly twofold compared with proestrus $(P<0.0001)$ and falling to prepregnancy levels by day 18 ( $P<0.0001$; Fig. 1 E).

Published by Bioscientifica Ltd. 
A
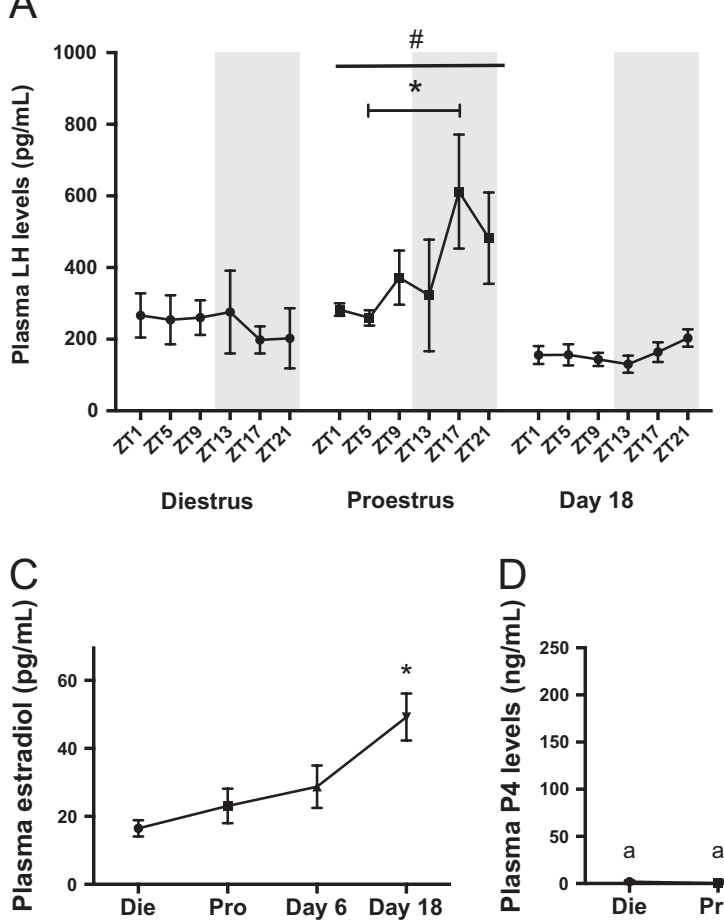

$B$

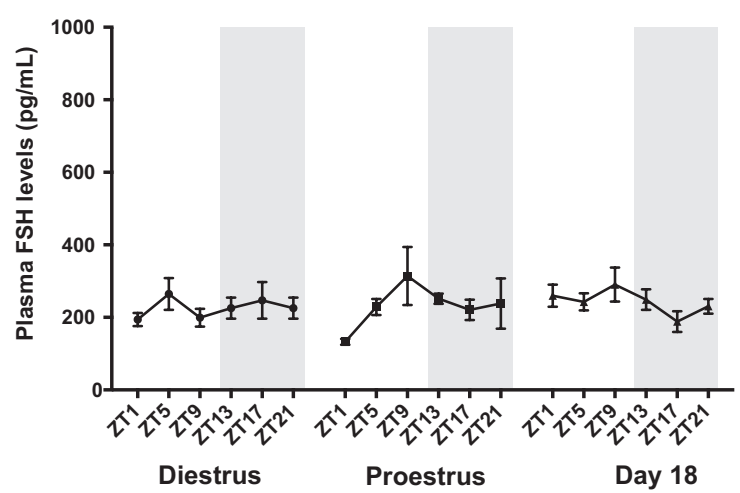

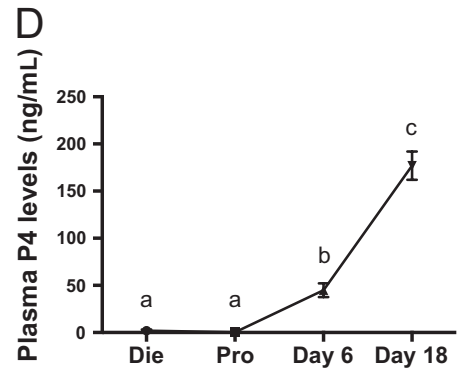

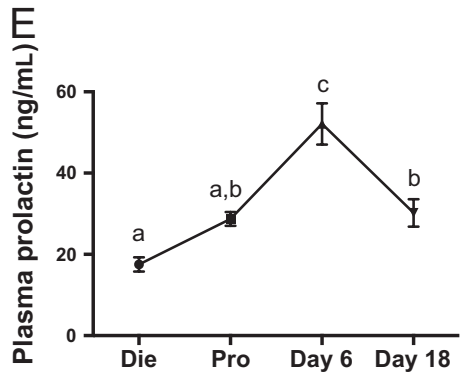

\section{Figure 1}

Plasma hormone concentrations in nonpregnant animals and during pregnancy. (A) LH levels peaked at ZT17 on the day of proestrus. (B) FSH levels were unchanged in nonpregnant animals and pregnant mice. (C) Estradiol levels were significantly increased at day 18 of pregnancy compared with day 6 proestrus (Pro) and diestrus (Die). (D) Progesterone (P4) levels were significantly increased at day 6 of pregnancy and further increased at day 18 of pregnancy. (E) Prolactin levels peaked at day 6 of pregnancy. Data are mean \pm S.E.M., $n=4-7$ per group. Two-way ANOVA; ${ }^{*}<0.05$ within-day effect; ${ }^{\#} P<0.001$ between-day effect. For $C$ and $D$, values without common notations differ; $P<0.05$.

\section{Gene expression}

Kiss1 expression in the anterior hypothalamus, representing the AVPV population, differed significantly between days and peaked at day 10 of pregnancy, increasing twofold compared with diestrus $(P<0.001)$. As for within-day effects, on the day of proestrus, Kiss 1 increased more than two-fold from ZT9 to ZT13 $(P<0.05)$ and returned to baseline by ZT17 (Fig. 2A). No time-of-day variation was observed during diestrus or any other day of pregnancy (Fig. 2A). In the posterior hypothalamus, representing the ARC population of KISS1 neurons, no change was noted between days. Within days, Kiss 1 levels increased over fourfold from ZT5 to ZT9 $(P<0.05)$ and returned to baseline by ZT13 on day 18 of pregnancy, whereas diurnal variation was not observed on any other day of pregnancy, diestrus, or proestrus (Fig. 2B).

Kiss1r expression in the anterior hypothalamus was different among days $(P<0.0001$; Fig. 3), with elevated mRNA levels at day 14 of pregnancy, having nearly doubled compared with diestrus $(P<0.0001)$, but showed no diurnal variation on any day of the cycle or pregnancy.
Avp expression in the anterior hypothalamus changed between days as pregnancy progressed $(P<0.0001)$; levels peaked in the late stages, with an increase of 2.4-fold from day 10 to day 14 of pregnancy $(P<0.0001)$, which was sustained at day $18(P<0.01)$. However, no diurnal variation was observed at any stage (Fig. 4A).

There was an effect of day on Avpr1a mRNA levels in the anterior hypothalamus $(P<0.0001)$; Avpr1a was high throughout diestrus/proestrus and the early stages of pregnancy, then decreased by 55\% from day 10 to days 14 and 18 of pregnancy $(P<0.0001$; Fig. 4B). As for withinday effects, Avpr1a levels in the anterior hypothalamus increased nearly two-fold from ZT1 to ZT5 during proestrus $(P<0.05)$ and 1.6 -fold between ZT5 and ZT13 on day 10 of pregnancy $(P<0.05$; Fig. $4 \mathrm{~B})$.

$N p v f$ expression in the posterior hypothalamus, representing the dorsomedial hypothalamus (DMH) population of RFRP-3 neurons, was different among days $(P<0.05)$, with mRNA levels declining after day 10 of pregnancy to $65 \%$ by day $18(P<0.05)$. However, diurnal variation was not observed at any stage (Fig. 5A). Npffr mRNA levels in the anterior hypothalamus varied across

Published by Bioscientifica Ltd. 

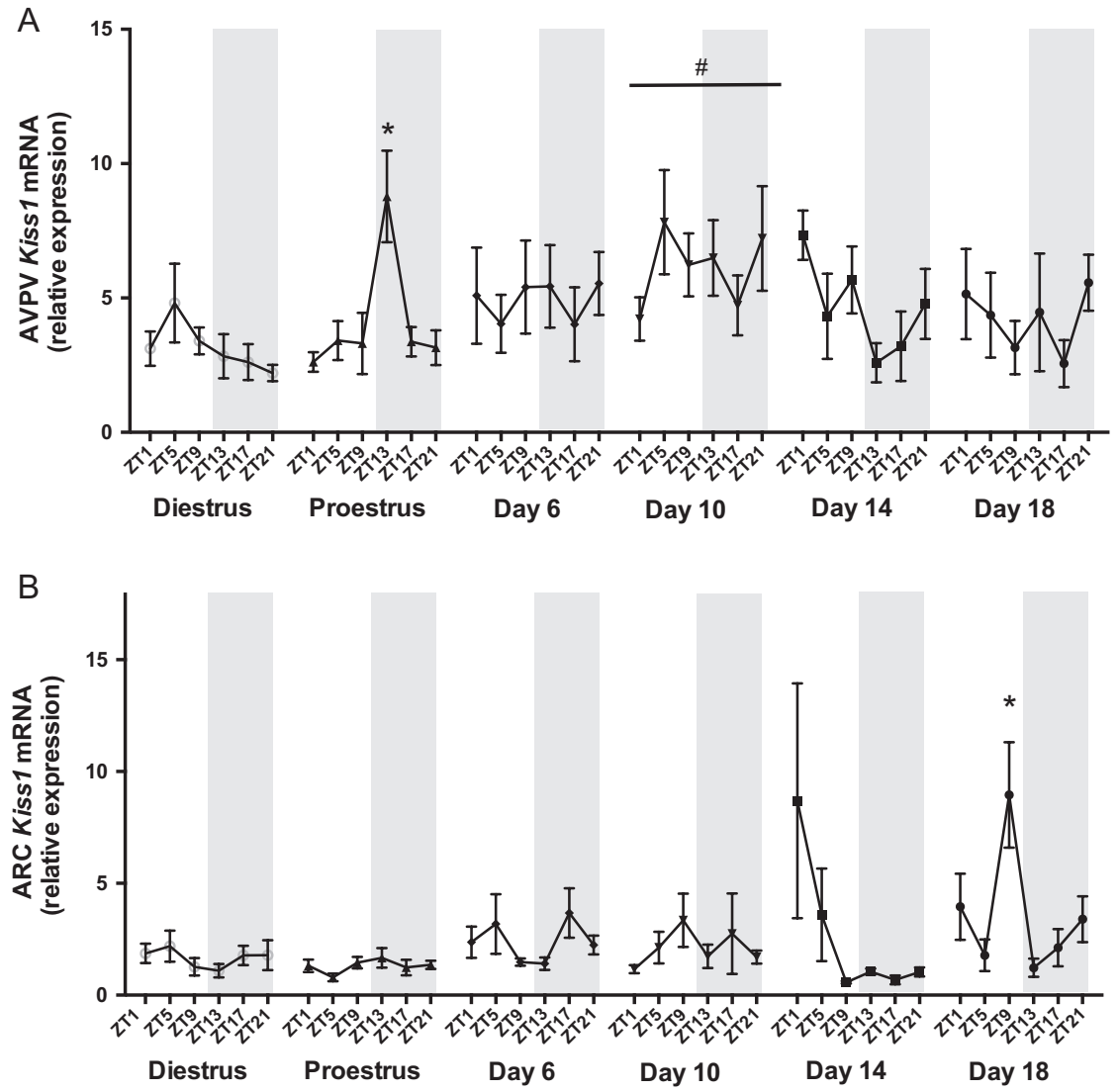

Figure 2

Kiss1 diurnal gene expression in nonpregnant animals and during pregnancy. (A) Kiss1 levels in the AVPV were significantly increased at ZT13 on the day of proestrus. This effect was not seen at diestrus or during pregnancy. (B) Diurnal variation in Kiss 1 seen at day 18 of pregnancy in the ARC. Data are mean \pm s.E.M., $n=5-7$ per group. Two-way ANOVA; ${ }^{*} P<0.05$ within-day effect; $\# P<0.001$ between-day effect compared with diestrus.

pregnancy $(P<0.01)$; Npffr was high throughout diestrus/ proestrus and the early stages of pregnancy, then fell by $55-65 \%$ at day 14 through to day 18 of pregnancy $(P<0.01)$. As for time-of-day effects, Npffr levels increased 3.5-fold from ZT1 to ZT13 $(P<0.01)$ during proestrus, but there was no diurnal variation evident at diestrus or during pregnancy (Fig. 5B).

Bmal1 and Rev-erb $\alpha$ exhibited strong time-of-day effects on both diestrus and proestrus $(P<0.05$ for both genes on both days) (Fig. 6). They also demonstrated an antiphase relationship, with Rev-erb $\alpha$ peaking in the afternoon between
ZT5 and ZT9, and Bmal1 peaking in the early hours of the morning between ZT21 and ZT1 (Fig. 7). Bmal1 and Rev$e r b \alpha$ and other central circadian clock genes also exhibited robust diurnal rhythms during pregnancy, which appeared unchanged despite an apparent upward shift in overall expression from mid-to-late gestation (Wharfe et al. 2016).

\section{Discussion}

The present findings demonstrate an alteration in the diurnal regulation of AVPV Kiss1 and Avpr1a expression

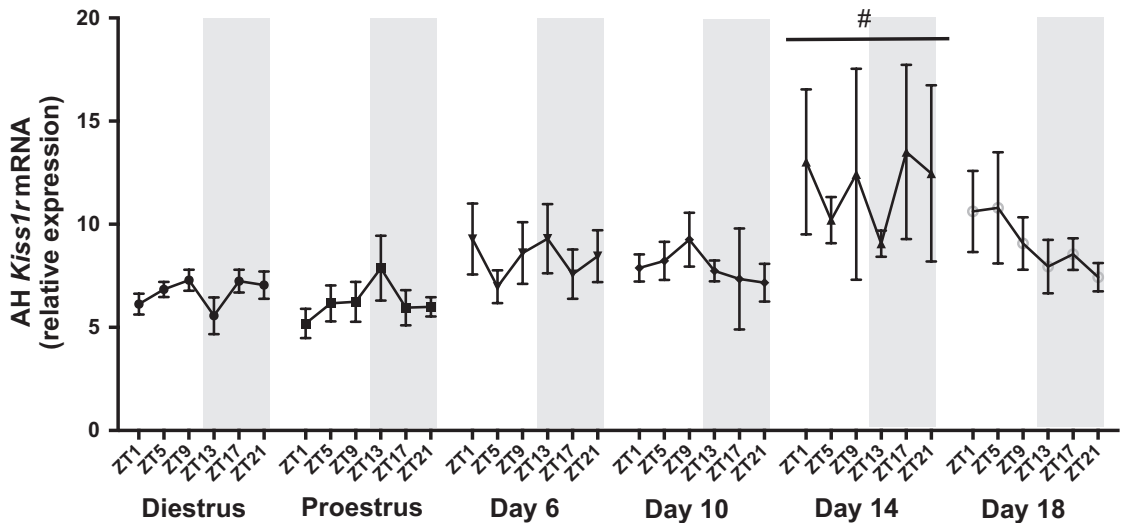

Figure 3

Anterior hypothalamus Kiss1r diurnal gene expression in nonpregnant animals and during pregnancy. No diurnal variation was observed at any stage. Data are mean \pm S.E.M., $n=5-7$ per group. Two-way ANOVA; ${ }^{P}<0.0001$ between-day effect compared with diestrus and proestrus. http://joe.endocrinology-journals.org DOI: 10.1530/JOE-16-0086
(C) 2016 Society for Endocrinology Printed in Great Britain 


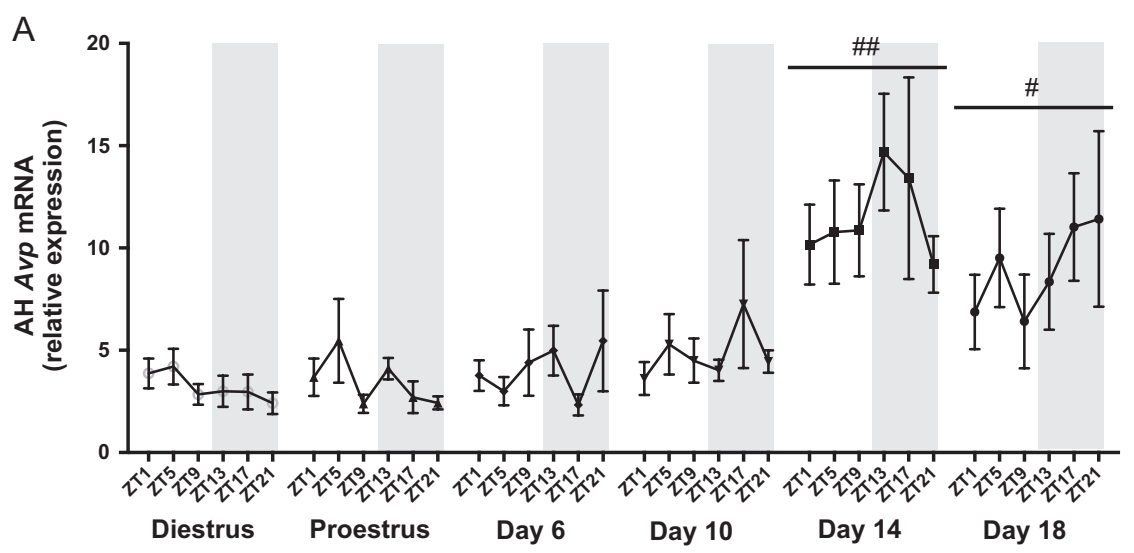

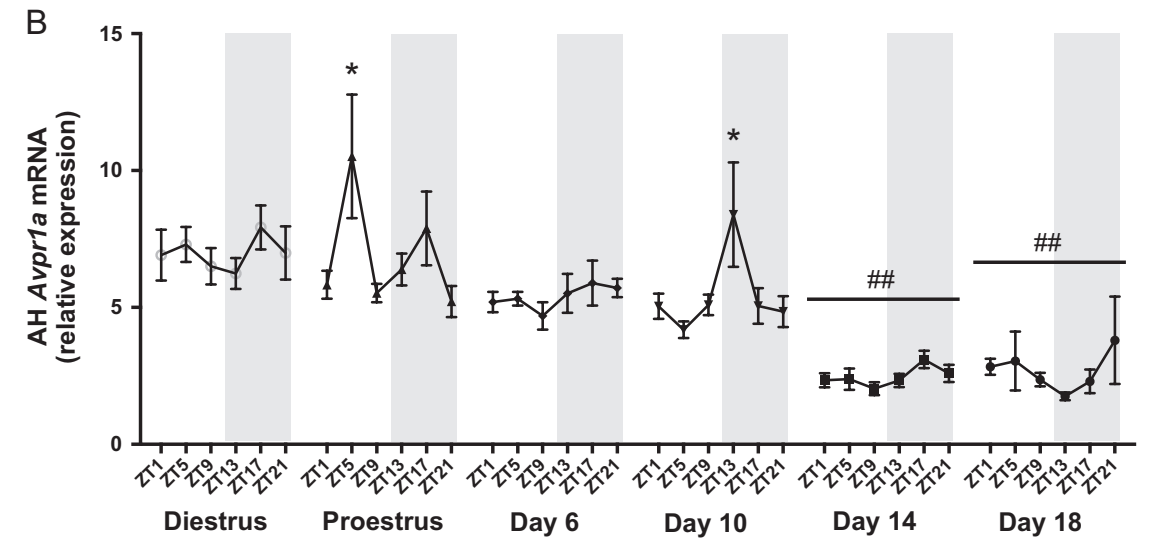

\section{Figure 4}

Avp and Avpr1a diurnal gene expression in the anterior hypothalamus in nonpregnant animals and during pregnancy. (A) Avp mRNA levels did not exhibit diurnal variation at any stage. (B) Avpr1a expression increased at ZT5 on the day of proestrus and showed some diurnal variation at day 10 of pregnancy. Data are mean \pm S.E.M., $n=5-7$ per group. Two-way ANOVA; $* P<0.05$ within-day effect compared with ZT1 and days 9, 13 , and $21 ; \# P<0.01$, $\# P<0.0001$ between-day effect compared with diestrus, proestus, and days 6 and 10 . during pregnancy in the mouse, which is associated with the cessation of the preovulatory LH surge, in spite of elevated estradiol concentrations and a functional master circadian clock. Kiss 1 gene expression in the AVPV peaked at ZT13 during proestrus, $4 \mathrm{~h}$ before the LH peak at ZT17, which is consistent with that reported in the literature, although the peak in Kiss1 mRNA levels has previously been found to be roughly coincident with the LH surge (Smith et al. 2006, Robertson et al. 2009).

We also found that AVP receptor Avpr1a increased in expression in the AVPV at ZT5 during proestrus, before the rise in Kiss1 expression and the LH surge. This is consistent with work by de la Iglesia and colleagues on the rat model, showing a peak in Avpr1a gene expression $4 \mathrm{~h}$ before that of Kiss1 (Smarr et al. 2013). It is possible that this temporal arrangement of events may reflect the transmission of circadian information from the SCN to kisspeptin neurons in the AVPV, although the $8 \mathrm{~h}$ gap observed in this study decreases the likelihood of a direct connection between the two events. Although its receptor showed an increase in expression at proestrus, Avp itself did not mirror this increase at any time on the day of proestrus. However, previous data have shown that $A v p$ gene expression in the mice SCN follows a circadian pattern, being highest at the end of the day and lowest at the end of the night, although the sex of the mice was not specified (Dardente et al. 2004). This pattern of Avp expression would be consistent with the sequence of events observed in this study, which comprise the increase in Avpr1a and Kiss1 expression and subsequent LH surge. It is possible that in this study, the diurnal rhythm of Avp mRNA specifically within the SCN has been masked; numerous parvocellular and magnocellular neurosecretory cells of the paraventricular and supraoptic nuclei located in the anterior hypothalamus express AVP as well (Alves et al. 1998, Nomura et al. 2002). In situ hybridization is needed to determine Avp mRNA levels specifically in the SCN.

The transcription factor albumin D-site binding protein $(D b p)$ in the AVPV has been hypothesised to be the conduit through which AVP drives the circadian rhythm of Kiss 1 ; Dbp is capable of triggering Kiss1 transcription and exhibits elevated levels in the afternoon of proestrus, similar to Kiss 1 expression (Xu et al. 2011). Data from Kriegsfeld and coworkers suggest that the initiation of the LH surge by AVP is gated 

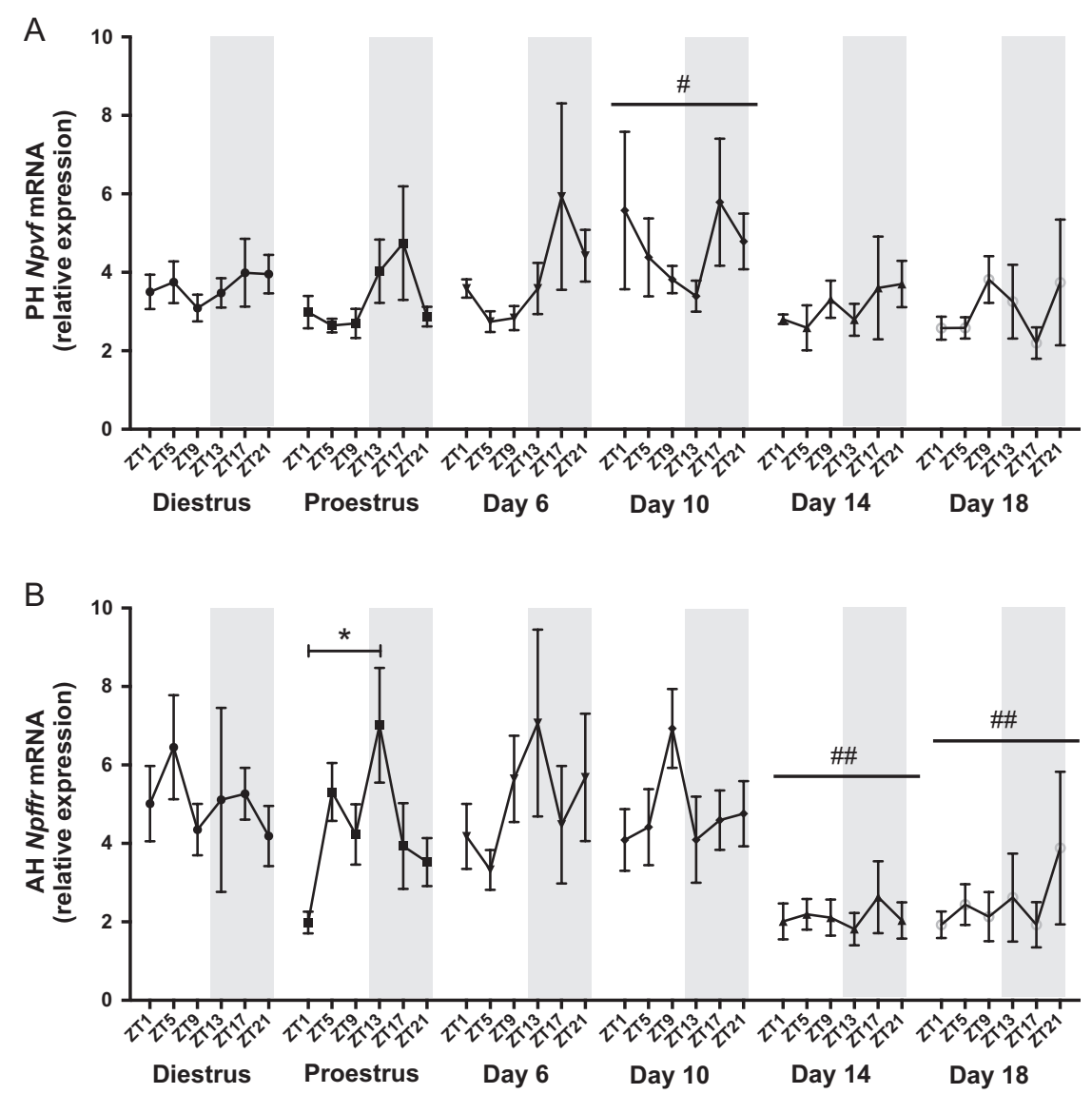

Figure 5

Npvf (Rfrp) and Npffr (Rfrpr) diurnal gene expression in nonpregnant animals and during pregnancy. (A) Npvf expression in posterior hypothalamus showed no diurnal variation at any stage. (B) Npffr expression in the anterior hypothalamus increased from ZT1 to ZT13 on the day of proestrus. Data are mean \pm S.E.M., $n=5-7$ per group. Two-way ANOVA; $* P<0.01$ within-day effect; $\# P<0.05$ between-day effect compared with days 6,14 , and $18 ; \# P<0.01$ between-day effect compared with diestrus, proestus, and days 6 and 10. by GnRH neurons, whereby kisspeptin neurons are indiscriminately activated by AVP but GnRH neurons are selectively responsive to kisspeptin stimulation, depending on the time of day (Williams et al. 2011). This mechanism of control ensures that the LH surge is limited to the late afternoon of proestrus. In a further layer of circadian control, AVPV kisspeptin neurons
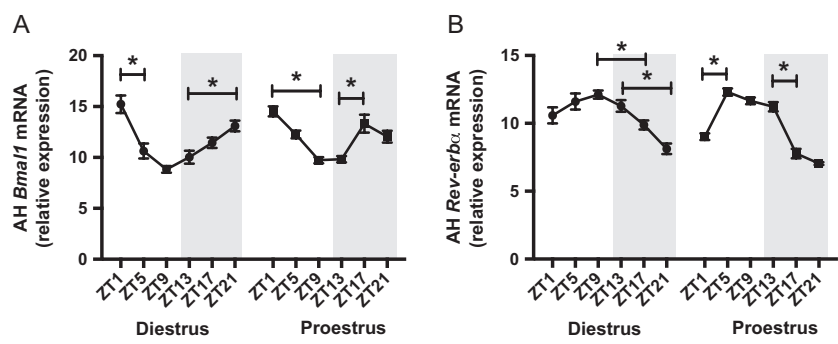

Figure 6

Anterior hypothalamus diurnal clock gene expression in nonpregnant animals. (A) Bmal1 expression showed a robust diurnal rhythm on diestrus and proestrus. (B) Rev-erb $\alpha$ showed a robust diurnal rhythm on diestrus and proestrus. Expected antiphase relationship between Bmal1 and Rev-erb $\alpha$ was observed. Data are mean \pm S.E.M., $n=5-7$ per group. Two-way ANOVA; $* P<0.05$ within-day effect. appear to possess a circadian oscillator independent of the master pacemaker in the SCN. Recent work by Chassard and coworkers demonstrates a daily period circadian clock 1 (PER1) rhythm within AVPV kisspeptin cells that is $\mathrm{E}_{2}$-sensitive and phase delayed compared with that in the SCN (Chassard et al. 2015), suggesting that there may exist yet another level of circadian gating of the LH surge.

In this study, both Kiss1 and Avpr1a mRNAs in the anterior hypothalamus exhibited a peak in expression during proestrus that was absent at diestrus. These estrous cycle differences in expression profiles do not appear to be driven by clock genes as the rhythms of Bmal1 and Rev-erb $\alpha$ were unchanged between diestrus and proestrus, suggesting that the likely major stimulus for the increase in Kiss1 and Avpr1a expression at proestrus is rising estradiol levels (Robertson et al. 2009, Williams et al. 2011, Smarr et al. 2013). Unlike Kiss1 expression in the AVPV, Kiss1 expression in the ARC was not different between proestrus and diestrus, exhibiting no diurnal variation on either day. The different expression patterns reflect the distinct roles of the two neuronal populations, with the kisspeptin neurons in the ARC responsible for the

Published by Bioscientifica Ltd. 


\section{Proestrus PM}

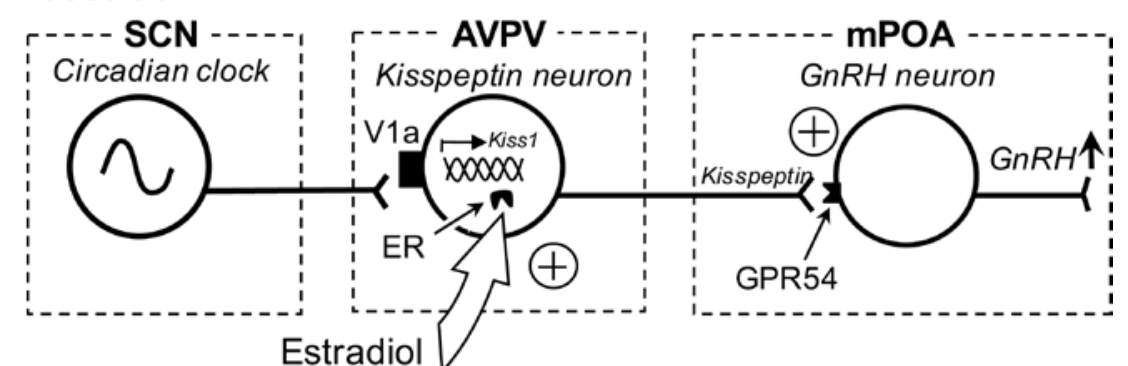

Late Pregnancy

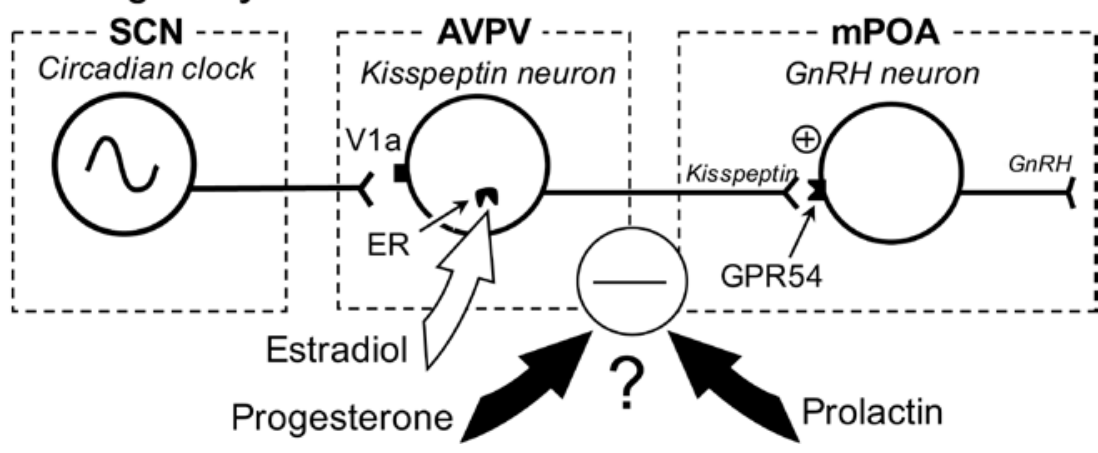

\section{Figure 7}

Proposed model indicating the change between proestrus and late pregnancy with the role of AVPV kisspeptin neurons in generating the $\mathrm{GnRH/LH}$ surge. At proestrus, kisspeptin neurons in the AVPV receive circadian information from the $\mathrm{SCN}$ via vasopressin receptors (V1a), and sense circulating estradiol via estrogen receptors (ER). Kisspeptin neurons are activated in the event that estrogenic and circadian signals are both high, activating GnRH neurons. In late pregnancy, despite high estrogen and an operant clock, there is a disruption of kisspeptin output possibly due to reduction in $\mathrm{V} 1 \mathrm{a}$ and high progesterone and/or prolactin. Figure adapted under the terms of a Creative Commons Attribution-NoncommercialShare Alike 3.0 Unported License from (Smith et al. 2006). tonic control of gonadotropin secretion, as opposed to generating the preovulatory LH surge (Smith et al. 2005b, Beale et al. 2014).

Diurnal rhythmicity in the SCN (as part of the anterior hypothalamus) during pregnancy remains intact, even though the expression of core clock genes (including Bmal1 and Rev-erb $\alpha$ ) is altered during pregnancy compared with diestrus (Wharfe et al. 2016). The persistence of these rhythms throughout pregnancy suggests that the master pacemaker in the SCN is functioning normally, and thus any changes in the circadian input to the AVPV are likely to occur downstream of the SCN. Consequently, the pathway that involves AVP neurons transmitting circadian information from the SCN to kisspeptin neurons in the AVPV is potentially disrupted in pregnancy (Leak \& Moore 2001, Williams et al. 2011).

Although the suppression of diurnal regulation of Kiss1 and Avpr1a expression in the AVPV during pregnancy compared with proestrus is consistent with our hypothesis, the mechanisms underlying this suppression are unclear and require further investigation. Despite the rise in estradiol levels throughout pregnancy, established in the literature and confirmed by our data, the surge in kisspeptin and LH does not occur at any stage of pregnancy. As both the LH surge and AVPV Kiss1 levels require the combination of elevated estradiol and a circadian signal (Robertson et al. 2009), the lack of an LH surge in the face of peak estradiol concentrations would indicate a disruption of the circadian signal.
Because diurnal rhythmicity of all the core clock genes in the SCN appears to be intact during pregnancy (Wharfe et al. 2016), one possibility is that there is an alteration in the AVP neuronal connections between the SCN and the AVPV, leading to a loss in circadian information. Alternatively, it could be that other hormone(s) that experience an upsurge during pregnancy are overriding the estrogenic and circadian signals that give rise to the increase in kisspeptin in the AVPV.

Potential candidate hormones are progesterone and prolactin, both of which are elevated in the plasma during pregnancy, as observed in this study, and exhibit expression patterns that are in agreement with previously reported data from both the rat and the mouse. Plasma prolactin concentrations are high in early pregnancy with a biphasic pattern of secretion, characterized by one nocturnal and one diurnal surge, which cease after day 8 of pregnancy (Smith \& Neill 1976). This coincides with the beginning of an increase in placental lactogen secretion (which peaks at day 11) (Smith \& Neill 1976), and there is evidence to suggest that the latter causes the former (Tonkowicz \& Voogt 1983). Prolactin levels fall and plateau in mid- and late pregnancy, then surge again immediately before parturition (Morishige et al. 1973, Murr et al. 1974a). Plasma progesterone exhibits almost the opposite pattern to prolactin, rising continually until very late in pregnancy, when levels fall precipitously to signal the onset of parturition (Murr et al. 1974b, Barkley

Published by Bioscientifica Ltd. 
et al. 1979, Waddell et al. 1989). Our data failed to capture the sudden decrease in progesterone levels before parturition; however, it is likely that this would have occurred at a later time had the pregnancies been allowed to progress further. In addition, recent work has shown that AVPV kisspeptin neurons require progesterone receptor signaling to display normal c-Fos induction and to mount an LH surge in response to elevated estradiol (Stephens et al. 2015). However, it does not appear to be gonadal progesterone but rather estradiol-induced local synthesis of neuroprogesterone in the hypothalamus that is critical for the LH surge (Micevych \& Sinchak 2011). Furthermore, kisspeptin expression in the ARC and AVPV is inhibited by high prolactin levels, resulting in the suppression of $\mathrm{LH}$ secretion (Araujo-Lopes et al. 2014, Brown et al. 2014). The substantial effects of progesterone and prolactin on kisspeptin, as well as the important role that these hormones play during gestation, likely implicate them in the disruption of circadian signaling, which results in the suppression of kisspeptin activation in pregnancy.

Although no diurnal regulation of AVPA Kiss1 mRNA expression during pregnancy was noted in our study, we did reveal a number of changes in gene expression during pregnancy. AVPV Kiss1 expression was elevated at day 10 of pregnancy compared with diestrus, in line with the findings of Roa and coworkers showing elevated Kiss 1 mRNA in the whole hypothalamus during pregnancy (Roa et al. 2006), although the authors suggest that this is not likely attributable to high levels of estradiol and progesterone. Moreover, at day 18, we saw a within-day increase in ARC Kiss1, despite relatively high estradiol levels and no observable increase in plasma LH levels. We also saw an increase in Kiss1r at day 18. Avp mRNA expression increased at day 14 and 18 of pregnancy, and within-day effects in Avpr1a were seen at day 10. We can only speculate what these changes reflect, but an attractive idea may be that changes relate to parturition or the phenomenon of postpartum ovulation in the mouse. Clearly, this requires further study.

Although this study demonstrated a $4 \mathrm{~h}$ time lag between the peak in Kiss1 mRNA levels and that of plasma LH levels, Robertson and coworkers have previously shown that these two events occur in synchrony (Robertson et al. 2009). This discrepancy in timing may be due in part to the shorter time intervals between collections in the Robertson et al. (2009) study; 1-2h intervals around the time of the LH surge, compared with $4 \mathrm{~h}$ intervals in this study, which may have failed to capture the true peak of LH concentrations as well as Kiss1 mRNA levels. In this study, another contributing factor could be the large variation in plasma LH concentrations at each time point. Samples were collected across a $1 \mathrm{~h}$ period, within $30 \mathrm{~min}$ of the designated time; thus, variations in shortlived peaks of LH levels would contribute to variation in the four-hourly measures.

Finally, we observed no difference in Npvf expression between diestrus, proestrus, or any stage of pregnancy. This is in contrast to some of the known literature, which indicates that RFRP expression is lowest at proestrus and maximal at diestrus (Gibson et al. 2008), consistent with its role as a GnRH inhibitor and in the negative feedback effects of estradiol present for the majority of the female mice ovulatory cycle (Kriegsfeld et al. 2006, Gibson et al. 2008, Ducret et al. 2009). The disparity between our data and previous research may be explained by the differing methods used to measure RFRP levels; Gibson and colleagues used immunohistochemical procedures to determine the number of RFRP-expressing cells (Gibson et al. 2008). In this case, it is likely that Npvf message levels are not an accurate reflection of RFRP protein levels; therefore, further studies using either western blots or immunohistochemistry are needed to confirm our results. Moreover, our anterior hypothalamus Npffr data would seem to show the inverse of the expected trend, with expression at proestrus increased around the time of the LH surge, suggesting that RFRP may even follow a similar pattern to kisspeptin activation. However, it is also important to note that there is currently no consensus in the literature on the regulation of RFRP neurons by estradiol. Estradiol treatment has been shown to have markedly different effects on RFRP levels in female rodents: in some instances decreasing (Molnár et al. 2011, Poling et al. 2012), increasing (Iwasa et al. 2012), or having no effect (Quennell et al. 2010).

The current findings reveal a spike in kisspeptin expression during proestrus that is concurrent with the preovulatory LH surge and preceded by an increase in AVP receptor expression, which may indicate the transmission of a circadian signal from the SCN. Pregnancy onset abolishes these temporal patterns and the subsequent LH surge. Although RFRP-3 may inhibit GnRH and/or gonadotropin secretion, we find that neither the peptide nor its receptor exhibits a lower level of expression during proestrus around the time of the LH surge; furthermore, there was no evidence of diurnal variation in RFRP-3 before or during pregnancy. Our data are the first to show that the diurnal variation in hypothalamic kisspeptin expression seen at proestrus is

Published by Bioscientifica Ltd 
abolished during pregnancy, in spite of high estradiol levels. We speculate that this is due to a disruption of the circadian signal, possibly along the SCN-AVPV pathway or at a hormonal level.

\section{Declaration of interest}

The authors declare that there is no conflict of interest that could be perceived as prejudicing the impartiality of the research reported.

\section{Funding}

This work was supported by the Western Australian Department of Health (grant number 1062158 2014).

\section{Acknowledgment}

The authors thank Dijana Tesic and Celeste Wale for their technical assistance.

\section{References}

Alves SE, Lopez V, McEwen BS \& Weiland NG 1998 Differential colocalization of estrogen receptor beta (ERbeta) with oxytocin and vasopressin in the paraventricular and supraoptic nuclei of the female rat brain: an immunocytochemical study. PNAS 95 3281-3286. (doi:10.1073/pnas.95.6.3281)

Araujo-Lopes R, Crampton JR, Aquino NSS, Miranda RM, Kokay IC, Reis AM, Franci CR, Grattan DR \& Szawka RE 2014 Prolactin regulates kisspeptin neurons in the arcuate nucleus to suppress LH secretion in female rats. Endocrinology 155 1010-1020. (doi:10.1210/en.2013-1889)

Barkley MS, Geschwind II \& Bradford GE 1979 The gestational pattern of estradiol, testosterone and progesterone secretion in selected strains of mice. Biology of Reproduction 20 733-738. (doi:10.1095/ biolreprod20.4.733)

Beale KE, Kinsey-Jones JS, Gardiner JV, Harrison EK, Thompson EL, Hu MH, Sleeth ML, Sam AH, Greenwood HC, McGavigan AK, et al. 2014 The physiological role of arcuate kisspeptin neurons in the control of reproductive function in female rats. Endocrinology 155 1091-1098. (doi:10.1210/en.2013-1544)

Boden MJ, Varcoe TJ, Voultsios A \& Kennaway DJ 2010 Reproductive biology of female Bmal1 null mice. Reproduction 139 1077-1090. (doi:10.1530/REP-09-0523)

Brown RSE, Herbison AE \& Grattan DR 2014 Prolactin regulation of kisspeptin neurones in the mouse brain and its role in the lactation-induced suppression of kisspeptin expression. Journal of Neuroendocrinology 26 898-908. (doi:10.1111/jne.12223)

Chassard D, Bur I, Poirel V-J, Mendoza J \& Simonneaux V 2015 Evidence for a putative circadian kiss-clock in the hypothalamic AVPV in female mice. Endocrinology 156 2999-3011. (doi:10.1210/ en.2014-1769)

Christian CA \& Moenter SM 2010 The neurobiology of preovulatory and estradiol-induced gonadotropin-releasing hormone surges. Endocrine Reviews 31 544-577. (doi:10.1210/er.2009-0023)

Clarke IJ, Qi Y, Puspita Sari I \& Smith JT 2009 Evidence that RF-amide related peptides are inhibitors of reproduction in mammals. Frontiers in Neuroendocrinology 30 371-378. (doi:10.1016/j.yfrne.2009.04.001)

Dardente H, Menet JS, Challet E, Tournier BB, Pevet P \& MassonPevet M 2004 Daily and circadian expression of neuropeptides in the suprachiasmatic nuclei of nocturnal and diurnal rodents. Brain Research. Molecular Brain Research 124 143-151. (doi:10.1016/j. molbrainres.2004.01.010)

Ducret E, Anderson GM \& Herbison AE 2009 RFamide-related peptide-3, a mammalian gonadotropin-inhibitory hormone ortholog, regulates gonadotropin-releasing hormone neuron firing in the mouse. Endocrinology 150 2799-2804. (doi:10.1210/en.2008-1623)

Gibson EM, Humber SA, Jain S, Williams WP3rd, Zhao S, Bentley GE, Tsutsui K \& Kriegsfeld LJ 2008 Alterations in RFamide-related peptide expression are coordinated with the preovulatory luteinizing hormone surge. Endocrinology 149 4958-4969. (doi:10.1210/en.2008-0316)

Gottsch ML, Cunningham MJ, Smith JT, Popa SM, Acohido BV, Crowley WF, Seminara S, Clifton DK \& Steiner RA 2004 A role for kisspeptins in the regulation of gonadotropin secretion in the mouse. Endocrinology 145 4073-4077. (doi:10.1210/en.2004-0431)

Iwasa T, Matsuzaki T, Murakami M, Kinouchi R, Osugi T, Gereltsetseg G, Yoshida S, Irahara M \& Tsutsui K 2012 Developmental changes in the mammalian gonadotropin-inhibitory hormone (GnIH) ortholog RFamide-related peptide (RFRP) and its cognate receptor GPR147 in the rat hypothalamus. International Journal of Developmental Neuroscience 30 31-37. (doi:10.1016/j.ijdevneu.2011.10.003)

Karsch FJ, Bowen JM, Caraty A, Evans NP \& Moenter SM 1997 Gonadotropin-releasing hormone requirements for ovulation. Biology of Reproduction 56 303-309. (doi:10.1095/biolreprod56.2.303)

Kriegsfeld LJ, Mei DF, Bentley GE, Ubuka T, Mason AO, Inoue K, Ukena K, Tsutsui K \& Silver R 2006 Identification and characterization of a gonadotropin-inhibitory system in the brains of mammals. PNAS 103 2410-2415. (doi:10.1073/pnas.0511003103)

Leak RK \& Moore RY 2001 Topographic organization of suprachiasmatic nucleus projection neurons. Journal of Comparative Neurology $\mathbf{4 3 3}$ 312-334. (doi:10.1002/cne.1142)

Levine JE 1997 New concepts of the neuroendocrine regulation of gonadotropin surges in rats. Biology of Reproduction 56 293-302. (doi:10.1095/biolreprod56.2.293)

Micevych P. \& Sinchak K 2011 The neurosteroid progesterone underlies estrogen positive feedback of the LH surge. Frontiers in Endocrinology 2 90. (doi:10.3389/fendo.2011.00090)

Molnár CS, Kalló I, Liposits Z \& Hrabovszky E 2011 Estradiol downregulates RF-amide-related peptide (RFRP) expression in the mouse hypothalamus. Endocrinology 152 1684-1690. (doi:10.1210/en.20101418)

Morishige WK, Pepe GJ \& Rothchild I 1973 Serum luteinizing hormone, prolactin and progesterone levels during pregnancy in the rat. Endocrinology 92 1527-1530. (doi:10.1210/endo-92-5-1527)

Murr SM, Bradford GE \& Geschwind II 1974a Plasma luteinizing hormone, follicle-stimulating hormone and prolactin during pregnancy in the mouse. Endocrinology 94 112-116. (doi:10.1210/ endo-94-1-112)

Murr SM, Stabenfeldt GH, Bradford GE \& Geschwind II 1974b Plasma progesterone during pregnancy in the mouse. Endocrinology $\mathbf{9 4}$ 1209-1211. (doi:10.1210/endo-94-4-1209)

Nomura M, McKenna E, Korach KS, Pfaff DW \& Ogawa S 2002 Estrogen receptor-beta regulates transcript levels for oxytocin and arginine vasopressin in the hypothalamic paraventricular nucleus of male mice. Brain Research. Molecular Brain Research 109 84-94. (doi:10.1016/S0169-328X(02)00525-9)

Poling MC, Kim J, Dhamija S \& Kauffman AS 2012 Development, sex steroid regulation, and phenotypic characterization of RFamiderelated peptide (Rfrp) gene expression and RFamide receptors in the mouse hypothalamus. Endocrinology 153 1827-1840. (doi:10.1210/ en.2011-2049)

Quennell JH, Rizwan MZ, Relf H-L \& Anderson GM 2010 Developmental and steroidogenic effects on the gene expression of RFamide related peptides and their receptor in the rat brain and pituitary gland. Journal of Neuroendocrinology 22 309-316. (doi:10.1111/j.13652826.2010.01963.x)

Published by Bioscientifica Ltd. 
Quennell JH, Howell CS, Roa J, Augustine RA, Grattan DR \& Anderson GM 2011 Leptin deficiency and diet-induced obesity reduce hypothalamic kisspeptin expression in mice. Endocrinology 152 1541-1550. (doi:10.1210/en.2010-1100)

Reppert SM \& Weaver DR 2001 Molecular analysis of mammalian circadian rhythms. Annual Review of Physiology 63 647-676. (doi:10.1146/annurev.physiol.63.1.647)

Roa J, Vigo E, Castellano JM, Navarro VM, Fernández-Fernández R, Casanueva FF, Dieguez C, Aguilar E, Pinilla L \& Tena-Sempere M 2006 Hypothalamic expression of KiSS-1 system and gonadotropinreleasing effects of kisspeptin in different reproductive states of the female Rat. Endocrinology 147 2864-2878. (doi:10.1210/en.2005-1463)

Robertson JL, Clifton DK, de la Iglesia HO, Steiner RA \& Kauffman AS 2009 Circadian regulation of Kiss1 neurons: implications for timing the preovulatory gonadotropin-releasing hormone/luteinizing hormone surge. Endocrinology 150 3664-3671. (doi:10.1210/en.2009-0247)

Russo KA, La JL, Stephens SB, Poling MC, Padgaonkar NA, Jennings KJ, Piekarski DJ, Kauffman AS \& Kriegsfeld LJ 2015 Circadian control of the female reproductive axis through gated responsiveness of the RFRP-3 system to VIP signaling. Endocrinology 156 2608-2618. (doi:10.1210/en.2014-1762)

Smarr BL, Gile JJ \& de la Iglesia HO 2013 Oestrogen-independent circadian clock gene expression in the anteroventral periventricular nucleus in female rats: possible role as an integrator for circadian and ovarian signals timing the luteinising hormone surge. Journal of Neuroendocrinology 25 1273-1279. (doi:10.1111/jne.12104)

Smith MS \& Neill JD 1976 Termination at midpregnancy of the two daily surges of plasma prolactin initiated by mating in the rat. Endocrinology 98 696-701. (doi:10.1210/endo-98-3-696)

Smith JT, Cunningham MJ, Rissman EF, Clifton DK \& Steiner RA $2005 a$ Regulation of Kiss1 gene expression in the brain of the female mouse. Endocrinology 146 3686-3692. (doi:10.1210/en.2005-0488)

Smith JT, Dungan HM, Stoll EA, Gottsch ML, Braun RE, Eacker SM, Clifton DK \& Steiner RA $2005 b$ Differential regulation of KiSS-1 mRNA expression by sex steroids in the brain of the male mouse. Endocrinology 146 2976-2984. (doi:10.1210/en.2005-0323)

Smith JT, Popa SM, Clifton DK, Hoffman GE \& Steiner RA 2006 Kiss1 neurons in the forebrain as central processors for generating the preovulatory luteinizing hormone surge. Journal of Neuroscience $\mathbf{2 6}$ 6687-6694. (doi:10.1523/JNEUROSCI.1618-06.2006)

Stephens SBZ, Tolson KP, Rouse ML, Poling MC, Hashimoto-Partyka MK, Mellon PL \& Kauffman AS 2015 Absent progesterone signaling in kisspeptin neurons disrupts the LH surge and impairs fertility in female mice. Endocrinology 156 3091-3097. (doi:10.1210/en.2015-1300)

Tonkowicz PA \& Voogt JL 1983 Termination of prolactin surges with development of placental lactogen secretion in the pregnant rat. Endocrinology 113 1314-1318. (doi:10.1210/endo-113-4-1314)

Vandesompele J, De Preter K, Pattyn F, Poppe B, Van Roy N, De Paepe A $\&$ Speleman F 2002 Accurate normalization of real-time quantitative RT-PCR data by geometric averaging of multiple internal control genes. Genome Biology 3 RESEARCH0034. (doi:10.1186/gb-2002-3-7research0034)

Waddell BJ, Bruce NW \& Dharmarajan AM 1989 Changes in ovarian blood flow and secretion of progesterone and 20 alphahydroxypregn-4-en-3-one on day 16 and the morning and afternoon of day 22 of pregnancy in the rat. Biology of Reproduction 41 990-996. (doi:10.1095/biolreprod41.6.990)

Wharfe MD, Mark PJ \& Waddell BJ 2011 Circadian variation in placental and hepatic clock genes in rat pregnancy. Endocrinology 1523552 3560. (doi:10.1210/en.2011-0081)

Wharfe MD, Mark PJ, Wyrwoll CS, Smith JT, Yap C, Clarke MW \& Waddell BJ 2016 Pregnancy-induced adaptations of the central circadian clock and maternal glucocorticoids. Journal of Endocrinology 228 135-147. (doi:10.1530/JOE-15-0405)

Williams WP \& Kriegsfeld LJ 2012 Circadian control of neuroendocrine circuits regulating female reproductive function. Frontiers in Endocrinology 3 60. (doi:10.3389/fendo.2012.00060)

Williams WP, Jarjisian SG, Mikkelsen JD \& Kriegsfeld LJ 2011 Circadian control of kisspeptin and a gated GnRH response mediate the preovulatory luteinizing hormone surge. Endocrinology 152 595-606. (doi:10.1210/en.2010-0943)

Xu Z, Kaga S, Tsubomizu J, Fujisaki J, Mochiduki A, Sakai T, Tsukamura H, Maeda K, Inoue K \& Adachi AA 2011 Circadian transcriptional factor DBP regulates expression of Kiss1 in the anteroventral periventricular nucleus. Molecular and Cellular Endocrinology 339 90-97. (doi:10.1016/j.mce.2011.03.020)

Received in final form 24 March 2016

Accepted 11 April 2016

Accepted Preprint published online 11 April 2016
(C) 2016 Society for Endocrinology Printed in Great Britain 